\title{
Model of Solid Waste Management (SWM) in Coastal Slum Settlement: Evidence for Makassar City
}

\author{
Nani Anggraini*†, Ramdiana Muis**, Fitri Ariani***, Sattar Yunus**** and Syafri***** \\ * Department of Environmental Engineering, Universitas Bosowa, Makassar, 90231, Indonesia \\ **Department of Urban and Regional Planning, Universitas Muhammadiyah, Pare-Pare, 91131, Indonesia \\ ***Department of Chemical Engineering, Universitas Bosowa, Makassar, 90231, Indonesia \\ ****Department of Mechanical Engineering, Universitas Muslim Indonesia, Makassar, 90231, Indonesia \\ *****Department of Urban and Regional Planning, Universitas Bosowa, Makassar, 90231, Indonesia \\ $†$ Corresponding author: Nani Anggraini; nani.anggraini@universitasbosowa.ac.id
}

Nat. Env. \& Poll. Tech.

Website: www.neptjournal.com

Received: 21-04-2020

Revised: $27-05-2020$

Accepted: 25-06-2020

Key Words:

Solid waste management

Slum area

Coastal settlement

Waste generation

\begin{abstract}
Makassar City slum settlement has a complex solid waste management problem located in a coastal area, divided by canals, inhabited by middle-class people who live with limited environmental facilities, and some build semi-permanent houses on the sea. This study aims to investigate the solid waste management in coastal slum settlement including waste generation, storage, collection system also community lifestyle, and coastal settlement characteristics. The method used in this study was quantitative and qualitative. The result of the analysis shows that the volume of waste generation category was about $49.47 \%$ compost potential, $25.57 \%$ inorganic recycling potential, and $24.96 \%$ residue material. Solid waste management is not going well in this area where most of the households did not get access to the communal trash bin and collection route. Recommendations for the solid waste management model are given to overcome existing problems by onsite composting and selling waste online and offline, and small amounts of residual waste discharged to the final disposal.
\end{abstract}

\section{INTRODUCTION}

Indonesia is one of the developing countries in the world, which is an archipelago and Makassar City is a metropolitan city located on Sulawesi Island. Makassar has a strategic position as it is located between the south and north in the provinces of South Sulawesi. Thus, the rapid growth of urbanization and industrialization within the area is unavoidable, resulting in Makassar being an area of mixed commercial-residential industrial along with the problem of water, air and soil pollution, which in turn can disturb human health (Sattar et al. 2012, Sattar et al. 2019). This, of course, requires efforts to overcome (Rashid et al. 2014).

In general, Solid Waste Management (SWM) is one of the most popular urban environmental problems in many developing countries because of the increase in urban, economic and industrial activities, especially in fast population exploding countries like India and Indonesia (Nyakaana 1996, Ramesh et al. 2009, Sattar et al. 2014). Poor Municipal SWM practices can result in land, water, and air pollution, improper disposal leads to the spreading of diseases and unhygienic conditions besides spoiling the aesthetics (Kirpalani et al. 2005, Raharjo et al. 2018). Furthermore, a gradual increase in waste generation coupled with inadequate services for solid waste management (SWM) intensifies the problems related to SW. This escalating problem has crucial effects on the environment, threatening the health of humans as well as incurring economic, biological and environmental losses (Moftah et al. 2016). The cities in a developing country using $20-55 \%$ of their budget in solid waste management, only $40-80 \%$ of the waste is collected (Yavini \& Musa 2013). The waste is transported to the final disposal site is just $63.9 \%$, the remaining small portion is managed at the source and the majority of the remainder is not transported so that it ends in an empty land, waterways, water bodies, and around the streets, and settlements. For the city of Makassar, 1,000 tons of garbage per day is transported to the final disposal with an open dumping system, the remaining 450 tons per day is not managed or not transported. Households are the biggest waste producer, reaching $62.99 \%$ compared to other sectors such as trade and services, offices and others (Indonesian Ministry of Environment 2012).

Recorded that $75 \%$ of households in Indonesia are not accustomed to sort out waste. Currently, there are widespread environmental movements initiated by the private sector, academics, and the government but their value has not shown significant changes (Indonesian Ministry of En- 
vironment 2012). When in fact, the separation of recyclable waste material would lead to a reduction in the quantity of solid waste (Sharma 2008). The fact, residents in villages or even sub-urban areas around $66.8 \%$ choose to burn waste and only $1.2 \%$ are recycled (Indonesian Ministry of Environment 2017). Another report suggested that this condition is exacerbated by the weak political power of those who realize the importance of environmental management. The struggle to preserve the environment is only supported by a small group of the middle class who lack political power in decision making, also stated that there were a few people who had knowledge but were still being environmentally unfriendly (Kutanegara 2014). So, what must be done is to build awareness, understanding, and community participation to behave in an environmentally friendly manner.

This study takes the area of research in the coastal settlements of Makassar city because it is one of the Waterfront Cities in Indonesia having many coastal settlements with a population of about 1,46 million people (Makassar Statistical Center 2019). Most of the coastal settlement in Makassar City was originally formed from the fisherman who utilizing marine resources as the source of life. However, dramatic city development transforms this settlement into slums with limited facilities of life, and one of their big problems is waste management.

Cambaya village is one of the slum settlements in the coastal area where some people build informal wooden houses over the sea with poor social services and amenities. This study was focused on waste management that takes place in this area. Solid Waste Management (SWM) defined as scientific disciplines related to generation control waste, storage, collection, transfer and transportation, and processing waste (Tchobanoglous 1993). The generation of solid waste depends on several factors such as lifestyle, habits of food, living standard, season, and commercial activities degree (Upadhyay et al. 2012). However, managing waste is a complex activity that required appropriate technical solutions, cooperation between all stakeholders, and adequate organization capacity (Marshal \& Farahbakash 2013).

Slum area identical to low-class people where the highest fraction of waste from this area is organic waste (Thakuria 2009, Miezah et al. 2015). In addition, the composition of urban waste is changing with the increasing use of packing materials and plastics (Asnani 2006). Furthermore, parameters of solid waste management will be an efficient support tool for the comparison and selection of effective alternative management of solid waste management programs (Qdais et al. 1997, Chang \& Davila 2008, Hancs et al. 2011). For this reason, it is necessary to collect and manage statistical data on waste management, which is usually inadequate, especially in developing countries (Buenrostro et al. 2001). Thus, a study on solid waste and its proper management to minimize its effect on the environment becomes of utmost importance. Therefore, this study tries to calculate the composition of waste, and divide it into potential components of compost, recycle, and residual waste. After that, community characteristics assessment survey was also conducted because participation from the community has a direct bearing on efficient SWM. The next stage was conducting an ongoing SWM assessment. In the absence of a basic facility of storage and collection of waste from source, communities are prone to dumping waste on the streets, open space, drains, and water bodies in the vicinity creating unsanitary situations (Asnani 2006). Finally, this study tries to give recommendations for the SWM model that can be applied.

\section{MATERIALS AND METHODS}

\section{Study Area Description}

Makassar city has many slum areas, but this study picked Cambaya Settlement because of its location on the coast, and it is divided by canals that drain water from large rivers in the upstream area. So, this area is a complex area for SWM research. Fig. 1 shows a map of Indonesia and the arrow is pointing to the location of Cambaya Village (5.110958 E,119.4248602 S). The village is situated close to the old city of Makassar. Fig. 2 displays the blow-up location of the slum area Cambaya that were divided into permanent and semi-permanent houses where some houses are built over the sea.

\section{Survey of Waste Generation}

This activity was conducted to calculate the volume, weight, and composition of waste generation from every household per day. This survey used the Indonesian National Standards (SNI) 19-3964-1994 concerning Methods for Taking and

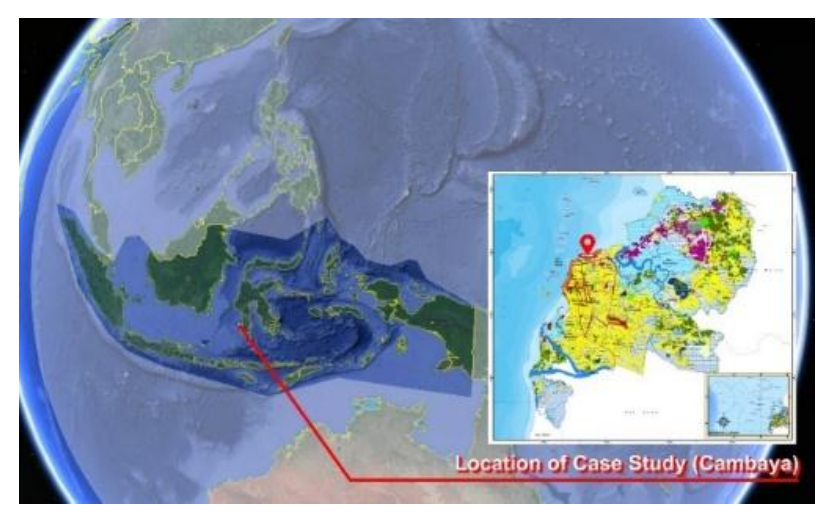

Fig. 1: Location of the case study 


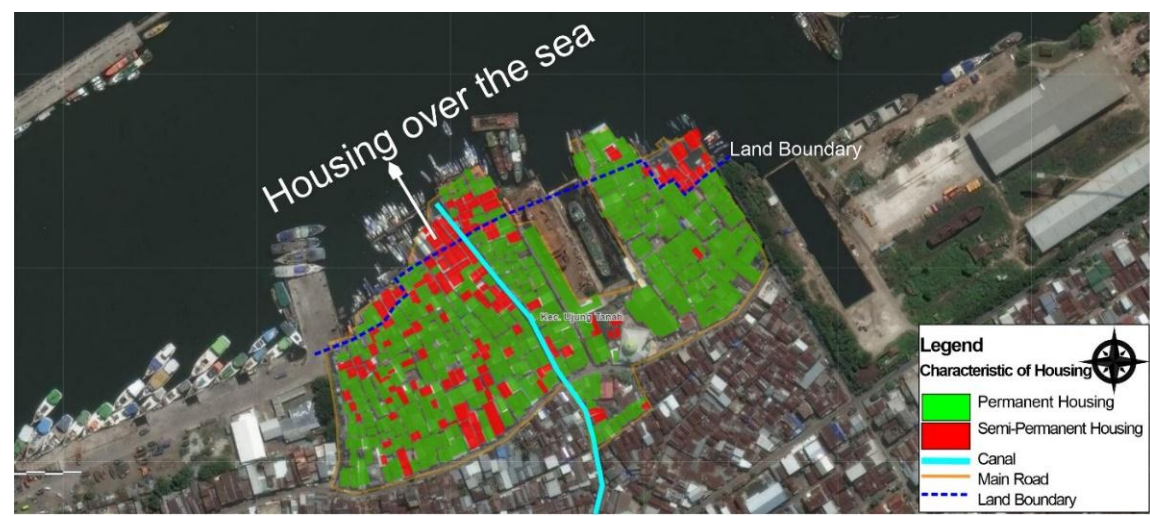

Fig. 2: Blow up location of Cambaya slum area.

Measuring Samples of the Generation and Composition of Urban Waste. The digital scale and volume measurement tools were used. For the determination of samples, the calculation used are as below.

$$
(\mathrm{K})=\frac{s}{n}
$$

$(\mathrm{S})=$ Number of People

(n) = Number of people per household

(S1) = proportion of the number of permanent housing/ high income households $=25 \%$

$(\mathrm{S} 2)=$ proportion of the number of semi-permanent housing/ moderate-income households $=30 \%$

$(\mathrm{S} 3)=$ proportion of the number of non-permanent housing/ low income households $=45 \%$

The garbage from housing:

1. permanent $=\mathrm{S} 1 \times \mathrm{K}$

2. semi-permanent $=\mathrm{S} 2 \times \mathrm{K}$

3. non-permanent $=\mathrm{S} 3 \times \mathrm{K}$

An effective solid waste management model is needed through the evaluation of the characteristics and rate of the solid waste generation which is one of the important first steps towards effective solid waste management (Qu et al. 2009, Tiruneh et al. 2015. Truong et al. 2017).

\section{Survey of Community Characteristics}

Survey questionnaires were carried out to find out the community lifestyle who lived in Cambaya village, where education level, household size, and income are significant factors that influence household generation rate (Truong et al. 2017). Questionnaires were distributed to respondents who live in two types of houses (permanent and semi-permanent). The questionnaire asked about solid waste management activities (sorting, storage, collecting, and transportation) and their current behaviour.
Direct interviews also were conducted with housewives who become the women leader of the community to explore the waste generation daily from the households. The village chief was also asked about the activities of the people. The data analysis technique used is a qualitative descriptive analysis technique by tabulating primary data.

\section{Mapping of Solid Waste Management}

The overlay map was used in the mapping of spatial coverage for the garbage collection vehicle route and trash bin user area using the ArcGIS application.

\section{RESULTS AND DISCUSSION}

\section{Settlement Characteristics}

Some of the buildings were built over the land boundary. The street in this settlement is a narrow alley about $50 \mathrm{~cm}$ in width. This situation makes it difficult to do several activities including waste management. Visualization of house characteristics is shown in Fig. 3.

Table 1 illustrates the general characteristics of the community. Most of the respondents were female, as solid waste management encourages the participation of females. Most of the respondents have a low level of education and have below the regional minimum wage. This situation influences their attitude towards waste management. It can be seen from the amount of garbage around residential areas and water bodies. A study found that the reasons for the waste management cases were lack of information relating to health, low knowledge level, tradition, culture, and economic situation as well as low level of living standard (Shahmoradi \& Rad 2009).

\section{Waste Generation Result}

Fig. 4 below describes the result of the waste generation survey of waste weight. From this survey, the average waste generation per household was $1.8 \mathrm{~kg}$ Organic Waste 


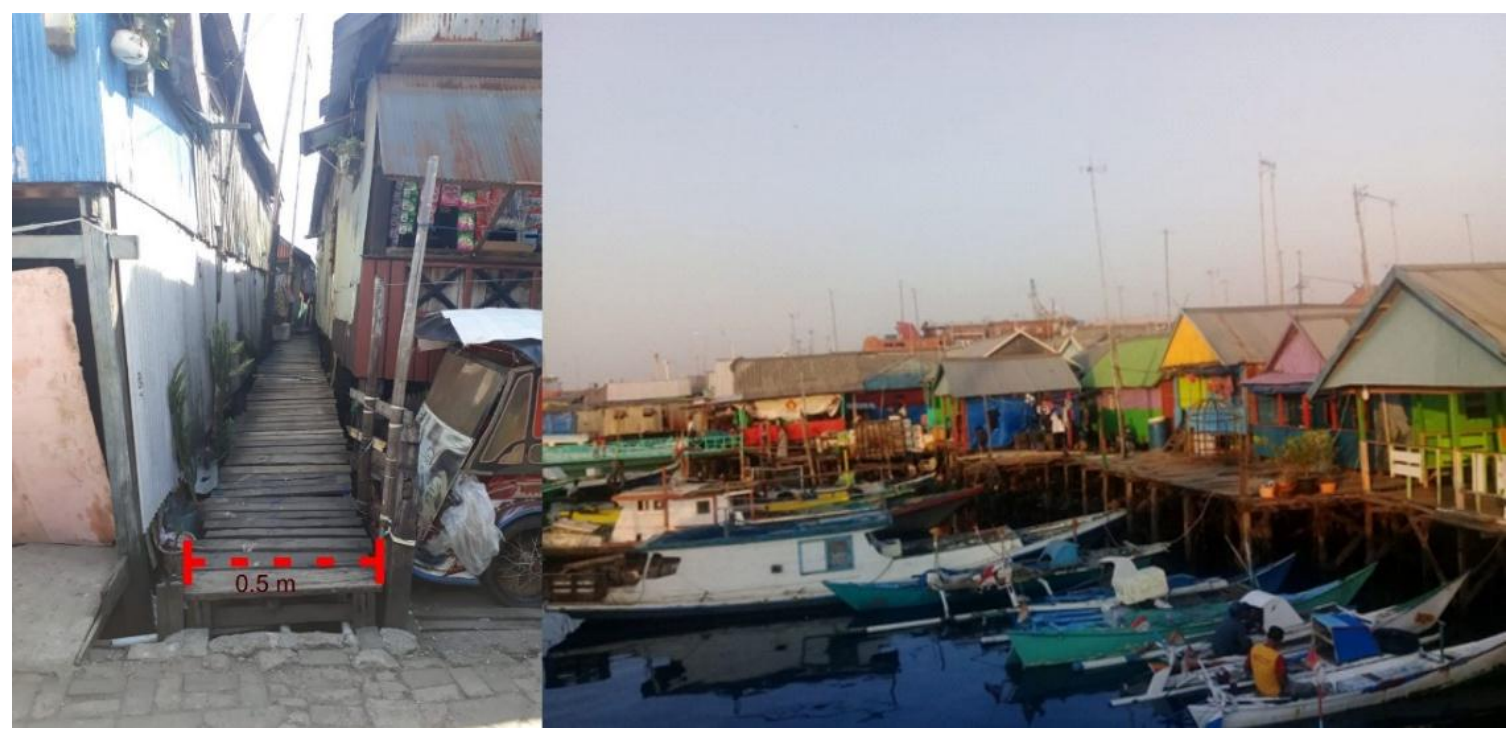

Fig. 3: Settlement characteristics.

per day per household, and inorganic waste $1.31 \mathrm{~kg}$ per day per household.

The volume of waste generated in the Cambaya Coastal Area was dominated by $58 \%$ organic waste and $42 \%$ inorganic waste. Furthermore, from Table 2 it can be concluded that if the onsite waste processing is done (onsite composting and recycle), only $24.96 \%$ will be transported to the final

Table 1: Characteristics of communities.

\begin{tabular}{|ll|}
\hline Characteristics & Value $(\%)$ \\
\hline Number of people per house & 15 \\
6 people & 39 \\
5 people & 20 \\
4 people & 26 \\
Others & \\
Livelihood & 35 \\
Fishermen & 41 \\
Labourer & 24 \\
Others & \\
Income per month & 50 \\
IDR 1,000,000-2,000,000* & 20 \\
IDR 2,000,000-3,000,000 & 30 \\
Others & \\
Education & 53 \\
Elementary School & 26 \\
Junior High School & 21 \\
Others & \\
\hline
\end{tabular}

*below the regional minimum wage disposal as residue. This waste was potentially thrown into the water bodies if there is no proper waste management. A study reported that Municipal Solid Waste (MSW) generally includes degradable (paper, textiles, food waste, straw, and yard waste), partially degradable (wood, disposable napkins, sludges) and nonbiodegradable (leather, plastics, rubbers, metals, glass, ash from fuel-burning like coal, briquettes, wood, electronic waste). Generally, Municipal Solid Waste is managed as a collection from the street and disposed of at landfills (Jha et al. 2008).

\section{Storage System}

The existing storage system was used as an individual, communal, and some of them throw trash directly into the water bodies (canal and sea) especially for those who live over the sea or in front of the canal. The communal trash bin is only in front of the main road as secondary solid waste storage, but most people use an individual

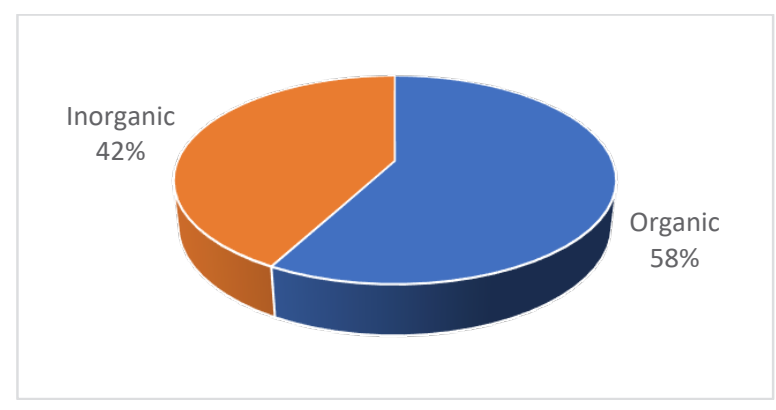

Fig. 4: Average percentage of the weight of organic and inorganic waste generation. 
Table 2: Waste component calculation.

\begin{tabular}{|lll|}
\hline Type of Garbage & Value $(\%)$ & Explanation \\
\hline $\begin{array}{l}\text { Organic (Compost } \\
\text { Potential) }\end{array}$ & 49.47 & Leftover, leaves, and twigs. \\
$\begin{array}{l}\text { Inorganic (Recycling } \\
\text { Potential) }\end{array}$ & 25.57 & $\begin{array}{l}\text { *Paper, plastic, metal, and } \\
\text { bottles }\end{array}$ \\
Residue & 24.96 & $\begin{array}{l}\text { Textiles, cloth, rubber, leath- } \\
\text { er, and other materials. }\end{array}$ \\
\hline
\end{tabular}

*Potential Recycling is adjusted to the data of items sold in the collectors (Waste Bank and Trash Mall)

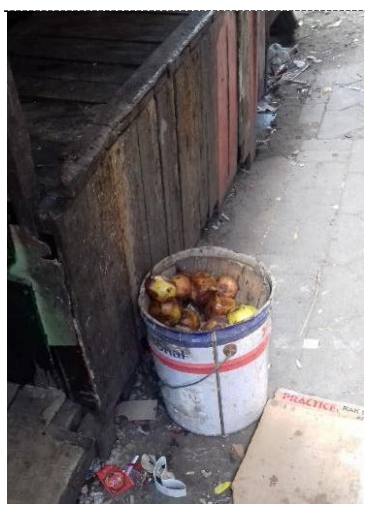

Fig. 6: Individual trash bin.

trash bin for primary solid waste storage. Some of the families collect rubbish from an individual bin and brought it to the communal bin located on the main road. The visualization of the type of trash bin used is shown in Figs. 5, 6, and 7.

Data from a previous study showed that about $80 \%$ of the community not yet separate their waste because of a lack of materials, knowledge, and motivation as well as they cared less about environmental conditions (Anggraini 2018).

\section{Collecting and Transport System}

The collection is carried out by janitors on the main road with the frequency of transportation as every day or 7 times a week. After collecting the garbage from households, they bring it to a temporary waste container. A cleaning fee is charged to the people. Type of the garbage collection vehicle is a three-wheeled motor (Viar). Most areas are not passed by Viar due to road conditions that cannot be passed by collection vehicles. This condition makes it difficult for the community, so some of them have to transport garbage independently to the communal trash bin, and some choose to dispose of their garbage around the settlement. Visualization of the collection service and route is shown in Fig 8. The mushrooming settlement colonies are developed in an unplanned way, thus, posing several constraints on the city's municipal services (Sharma et al. 2007).

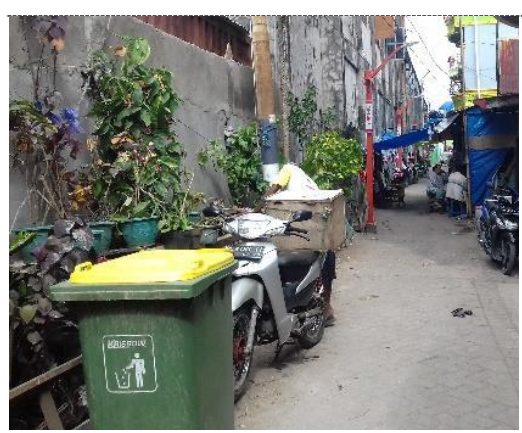

Fig. 5: Communal trash bin.

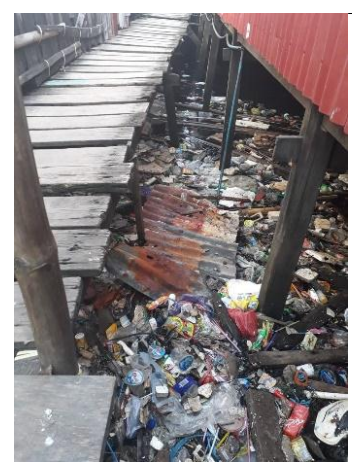

Fig. 7: No trash bin (Trash over water bodies).

\section{Existing Solid Waste Management Model}

The solid waste management model goes on as seen in Fig. 9. All garbage produced by households depends on transport personnel who have limited services so that not all garbage can be transported (about 20-30\% uncollected). People with low income also have limitations in paying waste fees.

\section{Recommendation of Solid Waste Management Model}

The design and operation of appropriate solid waste management systems are necessary for ensuring good sanitation and a clean environment (Gawaikar \& Deshpande 2006). The model in Fig. 10 shows the Solid Waste Management Recommendation Model for reducing the waste chain that leads to Final Disposal. This model is chosen to overcome the main problem faced in SWM, which is the limitations in terms of waste collection. This model wants to change the old paradigm of waste management that takes place in the research area to a new paradigm that is more sustainable by utilizing existing waste recycling agents.

The characteristics of settlements with narrow streets make it difficult to waste carts to enter, making it difficult for people to get services in terms of garbage collection. The limited facilities and knowledge about the environment give 


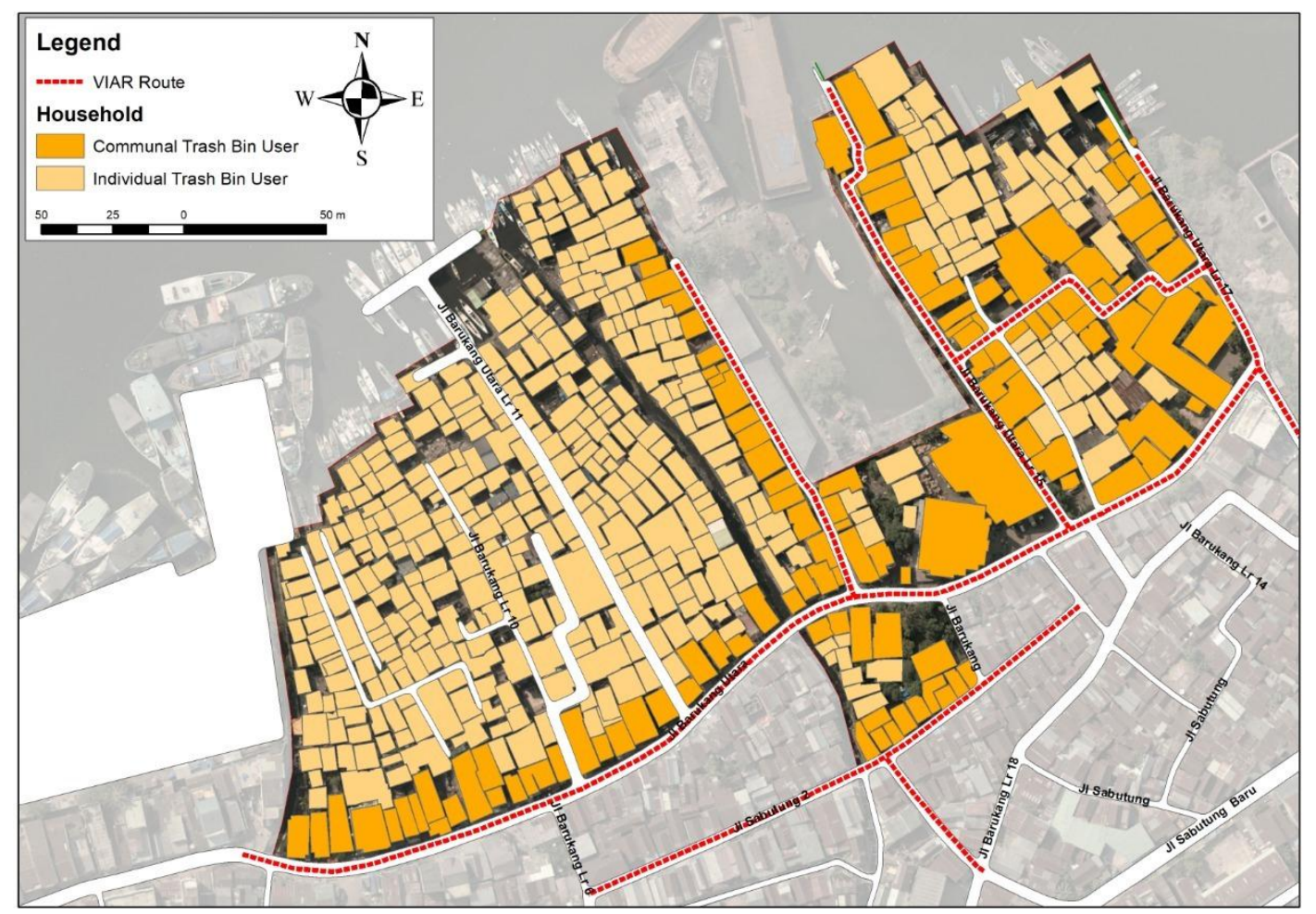

Fig. 8: Collecting vehicle route and trash bin user area.

the potential to dispose of waste into water bodies such as canals and the sea.

The solution of waste management is not limited to the end-of-pipe system, but management system such as waste reduction from its source, waste-sorting, until recycling process (Wijayanti et al. 2015). Recycling and compost concepts are considered pillars of sustainable solid waste management (Cheru 2011). Furthermore, recycling is one of the best methods of solid waste reduction. Similarly, the method can be applied in certain other aspects to decide on the most appropriate option to achieve the best expected results (Purohit et al. 2015). The existence of the Trash Mall and Waste Bank provides an opportunity for the community to sell recycled waste, the difference is that the Trash Mall uses an online system while the Waste Bank uses the offline system. Waste bank or "Bank Sampah" is the concept of waste management in Indonesia and developing countries in Southeast Asia in the management of recycled waste to get money in the form of savings that are established in an environment that is usually around 1000 inhabitants (Khair et al. 2019). The online system support by Trash Mall is something new, up to date by utilizing the technological sophistication of allowing the community to order via smartphone and recycled waste will be picked up by officers, this makes it easier than the offline system. In terms of sales prices, the offline system provides a slightly higher price, but the community needs to bring its

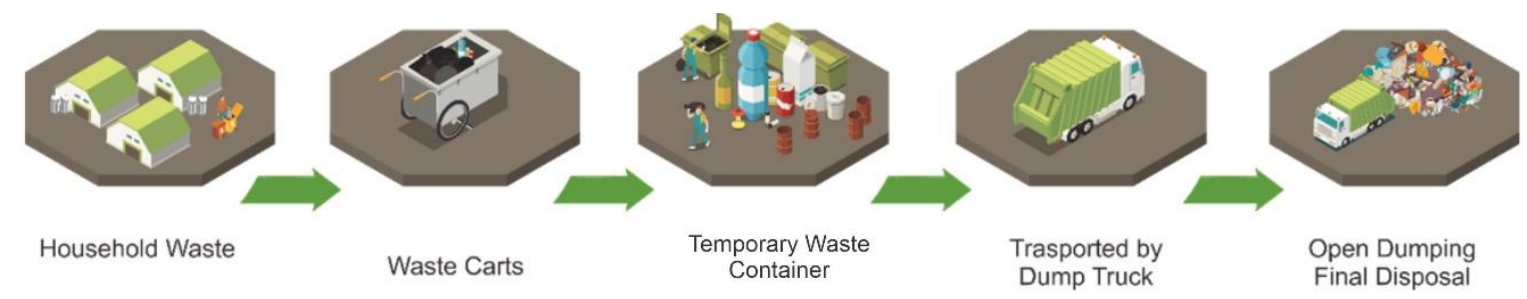

Fig. 9: Flow Diagram for existing solid waste management model. 


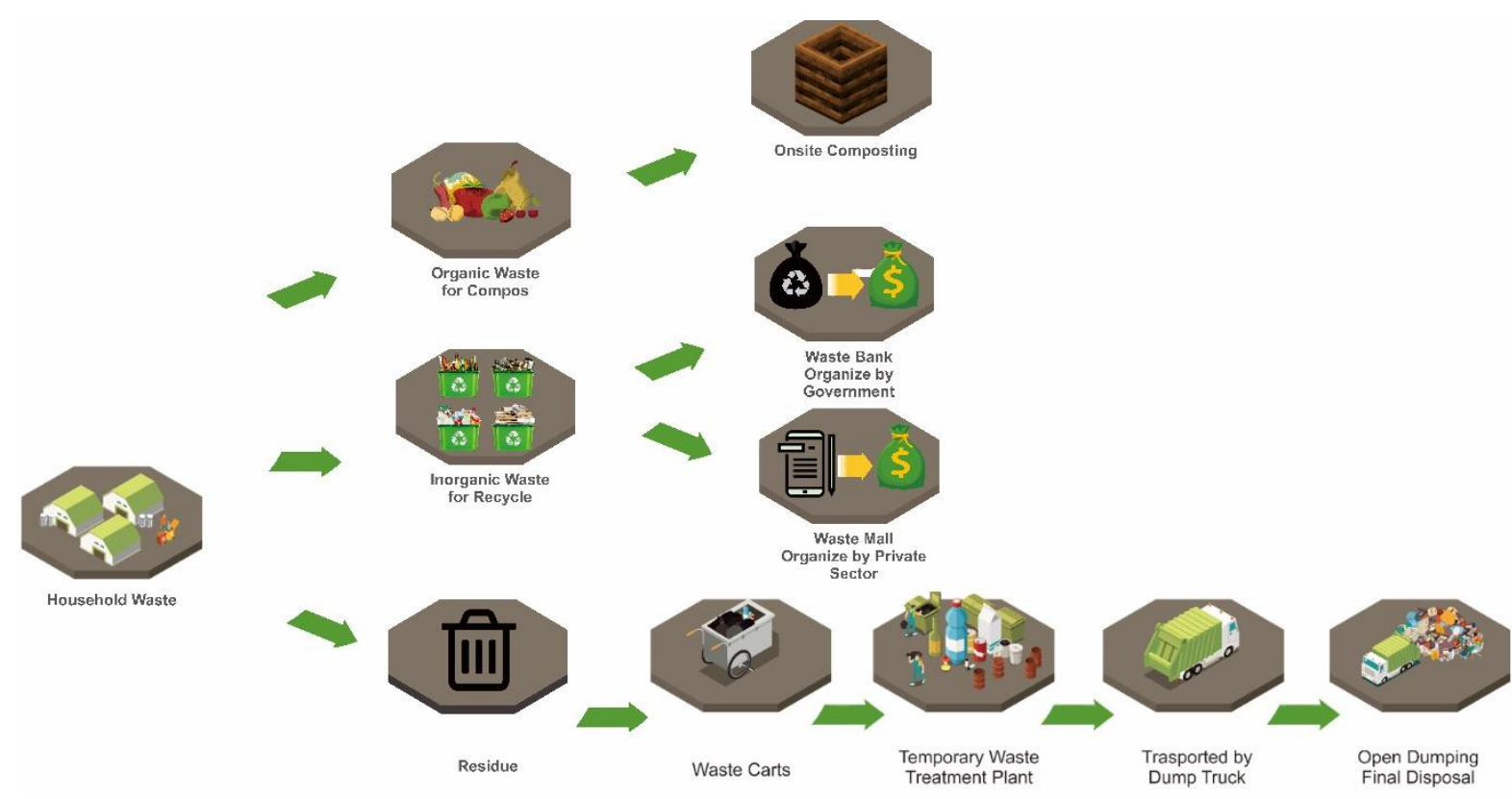

Fig. 10: Solid waste management recommendation model.

recycling waste to the nearest Waste Bank office. This model can be used for other residential areas especially those that have the same characteristics as the study area.

There is a need for onsite composting using both communal and individual systems because the organic waste potential for compost (leftover food, leaves, and twigs) is about $49.47 \%$. This system can be run by women who are mostly housewives. The remaining small amount is $24.96 \%$ residual waste will end up at the final disposal and become the responsibility of the government in its transportation and processing.

\section{CONCLUSION}

The study regarding solid waste management was carried out. The different factors and strategies of solid waste management were determined. Solid Waste Management in Cambaya coastal slum settlement is not going well yet because of several reasons such as characteristics of settlement, characteristics of citizens who live there, and lack of MSW facilities. The waste generation in Cambaya Village is dominated by organic waste $58 \%$ and inorganic waste $42 \%$. Most of the citizens did not get access to communal storage and collection, so potentially waste from households is thrown directly to water bodies. It needs serious waste management to minimize pollution of the coastal area. If properly managed according to the recommendations of the SWM model, only $24.96 \%$ of the residue will be transported to the final disposal.

\section{REFERENCES}

Anggraini, N. 2018. Study on the measurement of garbage dumps in the Cambaya coastal area. Multek Journal, 13(3): 550-558.

Asnani, P.U. 2006. India Infrastructure Report, Urban Infrastructure. Oxford University Press. New Delhi, India.

Buenrostro, O., Bocco, G. and Vence, J. 2001. Forecasting generation of urban solid waste in developing countries - A case study in Mexico. J. Air Waste Manage. Assoc., 51: 86-93.

Chang, N.B. and Davila, E. 2008. Municipal solid waste characterizations and management strategy for the Lower Rio Grandle Valley: Texas. Waste Manag., 28(5): 776-94.

Cheru, S. 2011. Assessment of Municipal Solid Waste Management Services in Dessie Town. Master Thesis, Addis Ababa University.

Gawaikar, V. and Deshpande, P. 2006. Source specific quantification and characterization of municipal solid waste. IE(I). Journal Env., 186: 33-38.

Hancs, A., Novak, P., Dvorak, M., Habart, J. and Svehla, P. 2011. Composition and parameters of household bio-waste in four seasons. Waste Manage., 31: 1450-1460.

Indonesian Ministry of Environment. 2012. Environmental Care Behavior Indicators (Results of a Survey of Environmental Care Behavior in 33 Provincial Capitals). Jakarta, Indonesia.

Indonesian Ministry of Environment. 2017. Indonesian Waste Management Information System. Jakarta, Indonesia.

Indonesian National Standards (SNI) 1994. SNI No.19-3964-1994 concerning Methods for Taking and Measuring Samples of the Generation and Composition of Urban Waste. Jakarta, Indonesia.

Jha, Arvind K., Sharma, C., Nahar Singh, Ramesh, R., Purvaja, R. and Gupta, Prabhat K. 2008. Greenhouse gas emissions from municipal solid waste management in Indian megacities: A case study of Chennai landfill sites. Chemosphere, 71: 750-758.

Kirpalani, C., Jain, N. and Bassin, J.K. 2005. Municipal solid waste management in Jaipur city: An overview. Nature Environment and Pollution Technology, 4(1): 143-148. 
Khair H., Siregar I. Y., Rachman I. and Matsumoto, T. 2019. Material for analysis of waste bank activities in Indonesia: Case study of Medan city. J. Indonesian Journal of Urban and Environmental Technology, 3(1): 28-46.

Kutanegara, P.M. 2014. Building an Indonesian Society that Cares About the Environment, Ministry of Environment of the Republic of Indonesia. Gadjah Mada University Press.

Makassar Statistical Center 2019. Makassar City Profile. Makassar, Indonesia.

Marshal, R.E. and Farahbakash, K. 2013. Systems approach integrated solid waste management in developing countries. J. Elsevier, 33: 988-1003.

Miezah, K., Danso, K.O., Kadar, Z., Fei-Baffoe, B. and Mensah, M.Y. 2015. Municipal solid waste characterization and quantification as a measure towards effective waste management in Ghana. J. Elsevier, 46: 15-27.

Moftah, S.A.W., Markovic, D., Moftah, S.A.O. and Nesseef, L. 2016. Characterization of household solid waste and management in Tripoli City-Libya. Open Journal of Ecology, 6: 435-44.

Nyakaana, J.B. 1996. Solid waste management in urban centers: The case of Kampala City-Uganda. J. East African Geographical Review, 19:1.

Purohit, Pulkit and Ramachandran, M. 2015. Selection of flywheel material using multicriteria decision making fuzzy topsis. Indian Journal of Science and Technology, 8(33). doi: 10.17485/ijst/2015/v8i33/80028.

Qdais, H.A., Hamonda, M.F. and Newham, J. 1997. Analysis of residential solid waste at generation sites. Waste Manage. Res., 15: 395-406.

Qu, X., Li, Z., Xie, X., Sui, Y., Yang, L. and Chen, Y. 2009. Survey of composition and generation rate of household wastes in Beijing, China. Waste Management, 29: 2618-2624.

Raharjo, S., Ruslinda, Y., Bachtiar, V.S, Regia, R.A, Fadhil, M., Rachman, I. and Matsumoto, T.S. 2018. Investigation on municipal solid waste characteristics from commercial sources and their recycling potential in Padang City, Indonesia. IOP Conf. Series: Material Science and Engineering, 288: 012134.

Ramesh, N., Meenambal, T. and Murugan, K. 2009. Municipal solid waste from Erode municipality, Tamilnadu, India. Nature Environment and Pollution Technology, 8(1): 21-28.

Rashid, M., Sattar, Y., Ramli, M., Sabariah and Puji, L. 2014. PM 10 black carbon and ionic species concentration of urban atmospheric in Makassar of South Sulawesi Province, Indonesia. J. Atmospheric Pollution Research, 5: 610-615: doi: 10.5094/APR.2014.070.

Sattar, Y., Rashid, M., Ramli, M. and Sabariah, B. 2014. Black carbon and elemental concentration of ambient particulate matter in Makassar
Indonesia. IOP Conf. Series: Earth and Environmental Science. 18. 012099: doi: 10.1088/1755-1315/18/1/012099.

Sattar Yunus., Mohd. Rashid., Ramli Mat., Sabariah Baharun and Hasfalina C. Man 2019. Characteristics of the $\mathrm{PM}_{10}$ in the urban environment of Makassar, Indonesia. J. Urban and Environmental Engineering, 13(1): 198-207: doi: 10.4090/juee. 2009. v13n1.198207.

Sattar, M. Rashid., R. Mat and L. Puji 2012. A preliminary survey of air quality in Makassar City South Sulawesi Indonesia. J. Teknologi (Sciences \& Engineering), 57: 123-136.

Shahmoradi, B. and Rad, S.M.M. 2009. Investigation on people's knowledge, attitude, and operation of municipal solid waste management in Sanandaj City, Iran. Nature Environment and Pollution Technology, 8(3): 539-544.

Sharma, A., Sharma, C. and Sharma, A.K. 2007. Characteristics and management of municipal solid waste in national capital territory of Delhi. Indian Journal Environmental Protection, 27(10): 897-904.

Sharma, R. 2008. Municipal solid waste management in Ajmer City, Rajasthan: An overview. Nature Environment and Pollution Technology, 8(4): 741-744.

Tchobanoglous, G., Hilary, T. and Samuel, V. 1993. Integrated Solid Waste Management. McGraw-Hill, Inc: New York.

Thakuria, M.N. 2009. A study on municipal solid waste management in Bongaigaon, Assam. Nature Environment and Pollution Technology, 8(4): 741-744.

Tiruneh, B.M., Venkateswarlu, M. and Gopala Krishna, B.V. 2015. Solid waste generation and solid waste disposal site management in urban areas: The case of Dessie Town, Amhara National Regional State, Ethiopia. International Journal of Advanced Scientific and Technical Research, 5(3): 293-307.

Truong, L.M., Trang T. T. and Dieu, T. T. M. 2017. Preliminary development a mathematical model for estimating household solid waste generation rate: the case of Ho Chi Minh City, Vietnam. Nature Environment and Pollution Technology, 16(2): 351-362.

Upadhyay, V., Jethoo, A. S. and Poonia M.P. 2012. Solid waste collection and segregation: A case study of MNIT Campus, Jaipur. J. IJEIT, 1(3).

Wijayanti, D.R. and Suryani, S. 2015. Waste bank as community-based environmental governance: A lesson learned from Surabaya. Procedia Social and Behavioral Sciences, 184: 171-179.

Yavini, T.D. and Musa, A.A. 2013. Municipal solid waste and pollution management in Jalingo Metropolis: Problems, challenges and strategies. J. Environment, 2(05): 125-133. 